\title{
EFFECT OF TURNAROUND STRATEGIES ON PERFORMANCE OF PUBLIC CORPORATIONS IN KENYA
}

\author{
Lucy Komen Birir*, Henry Kombo, Simon Kipchumba
}

Department of Business Administration, Faculty of Commerce, Egerton University, Kenya.

*Email of the corresponding author:lucyalbertk@gmail.com

Department of Business Administration, Faculty of Commerce, Egerton University, Kenya.

$$
\text { henrykombo@gmail.com }
$$

Department of Business Administration, Faculty of Commerce, Egerton University, Kenya.

$$
\text { Kipchumba7@gmail.com }
$$

\begin{abstract}
Many public corporations experiencing decline in performance have opted to implement turnaround strategies to improve their performance. This study extends previous research findings by seeking to examine the effect of turnaround strategies on performance of Public Corporations in Kenya, by identifying the turnaround strategies adopted in these Corporations, and to determine the effect of turnaround strategies on their performance. To achieve this objective, correlational research was adopted. The target population comprised 162 public corporations in Kenya. A purposive sample of thirty two (32) corporations was used in the study. A Likert type scale questionnaire was administered to respondents to collect data from the selected public corporations. Primary data was complemented with secondary data collected from the corporations for the previous three years. Data collected was edited and processed using Statistical Package for the Social Sciences (SPSS). Descriptive statistics that is in percentages were used to describe the research variables. Pearson's product moment coefficient was used to examine the relationship between turnaround strategies and organisational performance and multiple regression was used to establish the effect of turnaround strategies on performance of the corporations. The results showed a significant positive relationship between turnaround strategies and performance, $\mathrm{P}$-value $<0.05$. The positive relationship suggests that when declining corporations implement turnaround strategies (revenue generating and cost reduction strategies) their performance when measured using the balance scorecard measurement tool which measures financial perspective, customer satisfaction, internal business processes and innovation and learning perspectives, will improve positively. The findings also found that cost reduction strategies had a greater effect on the performance of public corporations in Kenya compared to revenue generating strategies. Therefore, it can be recommended that public corporations need to implement turnaround strategies to turn around declining corporations. The study also recommends areas of further research.
\end{abstract}

Keywords: Organisational performance, public corporations, turnaround strategy

Academic Discipline: Business Management, Strategic Management

Method: Literary Analysis

\section{Council for Innovative Research}

Peer Review Research Publishing System

Journal: International Journal Of Management \& Information Technology

Vol. 10, No 4

editorsijmit@gmail.com

www.ijmit.com 


\section{INTRODUCTION}

Organisations adopt various strategies to enhance their performance, to be competitive in the market and to achieve their objectives; these corporations have adopted various strategies. According to Byars, Rue, and Zahra (1996) these strategies are classified in various categories, they include stable growth strategy, which is used by companies that wish to maintain their objectives; this is a relatively low-risk strategy and is quite effective for successful organisations in an industry that is growing and in a nonvolatile environment. Growth strategy can be adopted by companies that wish to grow their business and there are several different generic strategies that fall in this category. They include concentration strategy, vertical integration and diversification. Harvesting strategies, are considered when a company attempts to "harvest" as much as they can, it entails minimum amount of investment with maximum short-term profits. Defensive strategy also referred to as retrenchment strategies are used when a company wants to reduce organisational operations, usually through cost reductions (cutting on non-essential expenditure) and asset reduction (disposing off equipment, selling land and reducing number of staff among others). However, the most common forms of defensive strategies are turnaround, divestment, liquidation, bankruptcy and becoming captive. There are also combination strategies which include simultaneous strategies or combinations. This study mainly concentrated on a specific retrenchment strategy that is designed to reverse the corporations' negative trend and get the organisation back on track to improved performance in terms of profitability, market share or service delivery, this strategy is turnaround.

In Kenya, Public Corporations are formed to achieve various objectives both commercial and social. Some Public Corporations exist to correct market failures. This is the case, where for instance, the service they give may not be profitably provided by the private investors, for example in tourism or infrastructure such as roads. Sometimes, they exist to meet explicit social and political objectives, such as providing education, health or even redistribute income or develop marginal areas.

\section{Turnaround Strategy}

According to Johnson, Scholes and Whittington (1995) in turnaround strategy is on speed of change, rapid cost reduction and revenue generation. Some of the main elements include: crisis stabilization - the aim of which is to regain control over the deteriorating position. There's likely to be short-term focus on cost reduction and revenue generation. In revenue generation and cost reduction, the model indicated to increase revenue, a company should ensure that marketing must be tailored to key market segments, pricing strategy that maximizes revenue, organisational activities focused on needs of target market segment; and additional opportunities exploited for revenue creation related to target market. Funds from reduction of costs are invested in new growth areas. In reducing costs they advocated for reducing labour costs and costs of senior management, focusing on productivity improvement, reducing marketing costs not focused on target market, tightening financial controls, tightening control on cash expenses, establishing competitive bidding for suppliers, deferring creditor payments, speeding up debtor payments, reducing inventory, and eliminating non-profitable products or services.

Management changes especially at the top level are usually required. This usually includes the introduction of the chief executive as well as changes in the composition of the board of directors. Gaining stakeholder support in a turnaround situation is important, it is vital that key stakeholders are kept informed of the situation now, as well as when it improves. Clarifying the target market is key to any turnaround success, consequently the turnaround strategy, while involving costcutting may require the business to conceptualise and reorient itself to the market. There is also evidence that a successful turnaround strategy involves getting much closer to customers and involving the flow of market information. Refocusing involves clarifying the target market which is likely to provide the opportunities to discontinue products and services that are either not targeted on those markets, eating up management time or not making sufficient financial contribution, while there may be also opportunities to outsource services. Financial restructuring involves changing the existing capital structure, raising additional finance or renegotiating agreements with creditors. Prioritization of critical improvement areas requires the ability of management to prioritise those things that give quick and significant improvements (Johnson et al., 1995).

\section{Organisational Performance}

One of the important questions in business has been why some organisations succeeded while others failed. Organisation performance has been the most important issue for every organization be it profit or non-profit one. It has been very important for managers to know which factors influence an organisation's performance in order for them to take appropriate steps to initiate them. However, defining, conceptualizing, and measuring performance have not been an easy task. Researchers among themselves have different opinions and definitions of performance, which remains to be a contentious issue among organisational researchers (Barney, 1997). Chong (2008) suggest that organizational performance can achieve efficient objectives or goals than economic results. This vision reveals that financial and economic measures present critical limitations in assessing performance. An alternative way is to apply the non-economic measures, though subjective in nature, as supplements to the economic. The combinations of these two measures economic and non-economic help the owners or managers to gain a wider perspective on measuring and comparing their entrepreneurial performance, in particular, the extent of effectiveness and efficiency in utilizing the resources, competitiveness and readiness to face the growing external pressure including globalizations (Chong, 2008).

In this study, the balanced scorecard model developed by Kaplan and Norton in 1991 was used to measure the effect of turnaround strategies on performance of public corporations in Kenya. The model groups measures of performance into four distinct categories of performance (financial perspectives, customer satisfaction, internal business processes, and innovation and learning perspectives). 


\section{Public Corporations in Kenya}

Public Corporations were first established in Kenya by the colonial government to provide essential services to the white settlers. Indigenous Africans' participation in economic activities such as trade and cash crop farming was generally discouraged. The original Kenyan Public Corporations were cartel-like organisations, and were set up to handle the products of European-owned farms, including sisal, pyrethrum, flax, and pigs. In the 1950s, farm products accounted by far for the greater part of the commodity exports of most tropical African countries (Jones, 1980). Eight Public Corporations were operating during World War II, while at independence (1963) Kenya inherited a framework of Public Corporations especially in the Agricultural Sector.

Following independence in 1963, therefore, the independent Kenya Government devised strategies to achieve three goals that were considered imperative for development: a fast overall economic growth rate, equitable distribution of development benefits and Kenyanisation of the economy. The means of achieving these goals were defined in Sessional Paper No. 10 of 1965 on African Socialism and its Application to Planning in Kenya, which states that, "under African Socialism, the power to control resource use resides with the state". From 1965 onwards, the government actively expanded and strengthened State Owned Enterprises (SOEs) as the vehicles of development and Kenyanisation. Indeed, as the SOEs proliferated in the first decade of independence, Kenya's economy grew apace at an impressive rate of $6.8 \%$. Economic growth, however dropped marginally to $5 \%$ in the $80 \mathrm{~s}$, and further declined to a mere $0.3 \%$ in $1990 \mathrm{~s}$.

The late 1980s saw a paradigm shift in the global politico-economic system, which emphasizes reforms that favour a free market economy. The thinking advocated by Breton Woods institutions such as the World Bank and the International Monetary Fund (IMF) led to the introduction of Structural Adjustment Programmes (SAPs) that pushed for liberalization of economies to pave way for private sector participation. SAPs are economic policies countries must follow in order to qualify for World Bank and IMF loans, SAPs are designed for individual countries but have common guiding principles and features which include export-led growth, privatization, liberalization and the efficiency of free market. The number of Public Corporations has reduced since then. Structural Adjustment Programs are programs which make it possible for countries to get a loan from the IMF or the World Bank. These loans are connected with conditionalities like significant policy reforms which have to be complied with before getting the loan (Abugre, 2000). In history the main agency providing structural adjustment lending was the World Bank. In 1986 the IMF also joined in providing adjustment loans and later other international financial institutions adopted the principle.

Public Corporations in Kenya are found in various sectors of the economy that include transport, trade and industry, agriculture, energy, education, tourism, housing, roads among others. These corporations are coordinated under various ministries. Thisstudy sampled 32 public corporations which have implemented turnaround strategies with a view to investigating the effect of specific turnaround strategies on their performance. Other studies have in the past established a link between corporate diversification strategy and resource constraints but the effect on performance especially in Kenyan Public Corporations have not been addressed.

\section{Statement of the Problem}

A turnaround strategy is designed to reverse a negative trend and get the organization back on the track to profitability. In Kenya this strategy has been implemented to reverse negative trends of public organisation. Much of the literature examining the effect of turnaround on performance has focused on private businesses, and other organisations abroad. The initial purpose of Public corporations in Kenya as vehicle for development and Kenyanisation worked well in the 1960's, however these corporations declined marginally in the 1980's and further in the 1990's. A policy decision to introduce Performance Contracts in the management of the Public Corporations was conveyed in the Economic Recovery Strategy for Wealth and Employment Creation (ERS), between 2003 and 2007. During that period Public Corporations implemented various corporate strategies including growth, harvesting and defensive strategies, defensive strategies include divestment, liquidation, captive and turnaround. To improve their performance, various public corporations adopted turnaround strategies in order to reverse their previously negative trend. According to Hofer, (1980) a link between severity of the downturn and the degree of cost and asset reductions that a firm should include in its recovery response was conceptualized, he referred to cost and asset reduction activities as operating turnaround strategies. Robbins and Pearce (1992), presented a model of turnaround based on evidence that business firm turnaround characteristically involved a multi-stage process in which retrenchment could serve as either a grand or operating strategy, while Proropsaltis et al. (2002) concluded in their study of UK hospitals, found that inadequacies in existing performance management systems mean that potential or actual failures often go undetected for long periods. Turnaround strategy probably is most appropriate when a corporation is in a highly attractive industry and its problems are pervasive but not yet critical. Turnaround emphasizes on the improvement of operational efficiency. However, there is little empirical work done to establish the effect between turnaround strategies and performance of corporations. In Kenya, there is no known study that has been done to measure extend on how turnaround strategies influenced the performance of the public corporations after implementation. This study, thus sought to examine the effect of turnaround strategies on performance of Public Corporations in Kenya.

\section{Objectives of the Study}

The overall purpose of this study was to examine the effect of turnaround strategies on performance of Public Corporations in Kenya. The specific objectives of the study were to:

i. Determine the effect of revenue generating strategies on organisational performance. 
ii. Determine the effect of cost reduction strategies on organisational performance.

iii. Determine the combined effect of turnaround strategies on organisational performance.

\section{Research Hypotheses}

This study sought to test the following hypotheses:

HA1: Revenue generating strategies have a positive effect on organisational performance

HA2: Cost reduction strategies have a positive effect on organisational performance.

HA3: The combined turnaround strategies have a positive effect on organisational performance.

\section{Limitations of the Study}

A limitation of this study is that the scope confined to Public Corporations in Kenya, however private firms and nongovernmental organisations have also implemented the turnaround strategy. The researcher however, observed that the findings can be implemented by firms and organisation irrespective of the nature of business.

\section{Literature Review}

\section{Turnaround Strategy}

The formulation of a strategy is one of the major management tools for coping with both external and internal challenges. This managerial process requires the art of matching and balancing between resources, skills, opportunities, and constraints (Hofer \& Schendel, 1978). Balancing means matching spending available resources, for instance, if there is a reduction in available finances, services should be respectively retrenched or assets should be sold. In addition, the authors emphasise that it is worthwhile and important that the organisational strategies be formally formulated. Hence, management should make a better forecast of possible developments and adapt policy to them, rather than improvise. Most importantly, a proper strategy can indeed result in superior performance and it has the potential to achieve the following purposes: development of organisational goals and objectives, identification of major organisational problems, allocation of resources, coordination and integration of complex organisations, development and training of managers, helping to forecast future performance, evaluation of management and stretching the thinking of top management.

The term "Strategy" has been defined as the direction and scope of an organisation over the long-term: which achieves advantage for the organisation through its configuration of resources within a challenging environment, to meet the needs of markets and to fulfill stakeholder expectation. Byars et al.(1996) explained turnaround strategies as trying to reduce operating costs, either by cutting "excess fat" and operating more efficiently or by reducing the size of operations. It seeks to redefine the company's business model in a way that results in additional or improved revenue streams. It also examines how the company spends money and applies return on investment (ROI) analysis to each sector of expense in order to improve the value received for each shilling spent.

Landrum and Gardner (2005) emphasised the broadness of strategic management and described it as a wide setting of goals, examinations, and behaviours, where the organisation promotes managerial cognitive processes, managerial abilities to coordinate intra organisational and inter organisational resources, and managerial abilities to support organisational learning. The Turnaround Process begins with a depiction of external and internal factors as causes of a firm's performance downturn. If these factors continue to detrimentally impact the firm, its financial health is threatened. Unchecked financial decline places the firm in a turnaround situation. A turnaround situation represents absolute and relative-to-industry declining performance of a sufficient magnitude to warrant explicit turnaround actions. A turnaround is typically accomplished through a two stage process. The initial stage is focused on the primary objectives of survival and achievement of a positive cash flow. The means to achieve this objective involves an emergency plan to halt the firm's financial hemorrhage and a stabilization plan to streamline and improve core operations. In other words, it involves the classic retrenchment activities: liquidation, divestment, product elimination, and down-sizing the workforce.

Retrenchment strategies are also characterized by the revenue generating, product/market refocusing or cost cutting and asset reduction activities. While cost cutting, asset reduction and product/market refocusing are easy to visualize, the idea of revenue-generating is best captured by a strategy that is characterized by increased capacity utilization, and increased employee productivity. According to Boyne et al. (2004), the balance of the evidence on private firms suggests that turnaround is influenced positively by retrenchment, repositioning and re-organisation. Although the evidence is mixed and contradictory in places, a clear majority of the empirical studies find that these strategies are associated with the reversal of financial decline in the private sector.

Retrenchment is an integral component of turnaround strategy. The critical role of retrenchment in providing a stable base from which to launch a recovery phase of the turnaround process is well established. Many firms that have achieved a reversal of financial or competitive decline inevitably refer to the presence of retrenchment as a precursor or prelude to the implementation of a successful recovery strategy (Bibeault, 1982; Finkin, 1985 and Goodman, 1982). The question remains, however, as to why retrenchment is so frequently an appropriate first step in an overall turnaround process. One possible explanation is that economic decline diminishes the firm's resource base hence Resource flexibility in the form of retrenchment provides an important tool in arresting financial decline. These heightened requirements stem from concurrent demands on the firm to overcome the destructive momentum of the established strategy and to cover the high 
startup costs of implementing the new strategic initiatives. Consequently, retrenchment may be necessary to stabilize the situation by securing or providing slack regardless of the subsequent recovery strategy that is chosen.

According to Bibeault (1982), this involves a return-to-growth or recovery stage; the turnaround process shifts away from retrenchment and moves towards growth and development and growth in market share. The means employed for achieving these objectives are acquisitions of new products, new markets, and increased market penetration. The importance of the second stage in the turnaround situation is underscored by the fact that primary causes of the turnaround situation have been associated with this phase of the turnaround process- the recovery response. Firms that declined primarily as a result of external problems, turnaround has most often been achieved through strategies based on revenue driven reconfiguration of business assets. For firms that declined primarily as a result of internal problems, turnaround has been most frequently achieved through recovery responses that were heavily weighted towards efficiency maintenance strategies. Recovery is said to have been achieved when economic measures indicate that the firm has regained its pre-downturn levels of performance. Between these two stages, a clear strategy is needed for a firm. As the financial decline stops, the firm must decide whether it will pursue recovery in its retrenchment reduced form through a scaled-back version of its preexisting strategy or shift to a return-to-growth stage. It is at this point that the ultimate direction of the turnaround strategy becomes clear. Essentially, the firm must choose either to continue to pursue retrenchment as its dominant strategy or to couple the retrenchment stage with a new recovery strategy that emphasizes growth. The degree and duration of the retrenchment phase should be based on the firm's financial health.

Slatter (1984) noted change of management, financial control, organizational change, asset reduction, cost reduction and investment. Lee, Mathur, and Gleanson (1998) pointed out that some actions also include asset sales, employee layoffs, acquisitions, mergers, bankruptcy filing, dividend cut and debt restructuring. Finally, Fisher, Lee, and Johns (2004) suggested recognition of decline problem, matching the solution to the cause of decline, replacement of the chief executive officer (CEO) or top management, retrenchment, and speed of action and rate of (pre-turnaround) decline of the distressed company.

In a study examining turnaround strategies for declining entrepreneurial firms, Rasheed (2002) observed that during an organisational life cycle, entrepreneurs choose between growth, stability or retrenchment strategies to overcome deteriorating trends in performance. The results indicated that entrepreneurs choose growth strategy when their perceptions of resource availability and past financial performance are both high.

In their study, investigating turnaround strategies in the realm of established small family businesses, Cater and Schwab (2009) examined turnaround commonalities at two exemplary family firms: a milk processor and a furniture retailer. They identified eight family-specific contingency factors that moderate the implementation of standard turnaround strategies. Their focus on three turnaround strategies provides an important starting point for the development of a more comprehensive theoretical framework of turnaround strategies for family firms that also includes later-stage turnaround strategies and captures turnaround success. This stream of research promises not only to advance theoretical understanding but also to improve how businesses implement turnaround strategies.

Boyne et al. (2004) the balance of the evidence on private firms suggests that turnaround is influenced positively by retrenchment, repositioning and re-organisation. Although the evidence is mixed and contradictory in places, a clear majority of the empirical studies find that these strategies are associated with the reversal of financial decline in the private sector.

In a study conducted by Beeri (2009), on private firms suggests that successful turnarounds are characterised by strategies of retrenchment, repositioning and reorganization. Failing companies that use one or more of these strategies are likely to perform better. A retrenchment strategy in local government could take a number of forms. The most drastic approach would simply be to stop providing a service that is performing poorly (i.e. to exit from the market completely). In many cases this would be impossible because of statutory obligations to ensure that services are provided. A more feasible form of 'exit' is to pass full or partial responsibility for service provision to other organizations (e.g. through contracting-out or partnership arrangements). Retrenchment could also involve disposal of underused assets (e.g. land premises, and equipment) or cutbacks in 'non-essential' activities, in order to reallocate resources to services that may deliver better value for money. As in the case of retrenchment, a strategy of repositioning in local government would be subject to statutory limits (e.g. it would not be feasible to expand the education service by building schools in other jurisdictions, or to diversify into the provision of hospitals and the payment of child benefit). Yet, even within these limits, many opportunities remain for repositioning. These include enhancing the range and quality of services, spreading existing services to cover new client groups, or providing new services (independently or in partnership) to existing client groups. The strategy of 'recovery through reorganization' can be applied directly in a local government context. Indeed, attempts to reform the culture, processes and management of local authorities appear to be widespread. A focus on reorganization in isolation suggests that success will follow from better delivery of existing services. Although this may be possible in some circumstances, it seems more likely that recovery requires reorganization in conjunction with retrenchment and/or repositioning. Their review of evidence on poorly performing hospitals, schools and local authorities showed that the most common recovery strategy in these sectors is reorganization, and in particular the replacement of head teachers, chief executives and service directors. A common finding from research on schools and local authorities is that turnaround is associated with greater clarity of priorities and better performance management.

In their analysis of the sustainability of the Indian railways turnaround, Sharma and Manimala (2007), foundthat it was not confined to the stage of arresting the decline, but reorienting, institutionalization and growth, one aspect which strengthened the conclusion of their study being in higher than initial stage of financial turnaround, is the alignment of the strategies with the diagnosis of operational inefficiency, lack of market orientation, lack of focus on core, lack of resources 
for growth. Indian railways turnaround challenges a widely held untested belief that private sector is synonym of efficiency and public sector by its very nature cannot be efficient and productive. Research study by Khandawala (2001), supports their conclusion that these beliefs are unfounded when put to empirical tests. The distinct contribution of their paper is twofold. Firstly, it provides practicing turnaround managers a model to help those making strategic decisions, Preoccupation or over-occupation with strategies resulting into financial recovery may be fatal. Adequate emphasis on institutionalizing and growth strategies is called for to sustain the performance recovery. Secondly, it applies the stage theory model to analyze the turnaround of the Indian Railways and provides an answer to a difficult question, whether the turnaround is sustainable.

Beeri (2009) reported that on turnaround management strategies (TMS), dealt with the linkage between public performance, public management, and public failure in the context of English local government. In this sense, it makes a significant step towards a better understanding of failing public organisations and the processes they undergo to improve their performance. Based on the combination of the case studies with the quantitative results, they concluded that TMS should be used after conducting a reliable diagnosis of organisational strengths, weaknesses, opportunities, and threats, and a fair ranking of the causes of the failure. Such a diagnosis would provide an accurate picture of the reality in which the organisation is performing and supply the basis for matching the required TMS to the specific causes of failure. Choosing the adequate strategies should be done after considering whether the set of strategies has the best chances to solve the organisation's problems after coordination of their order, time, and extent of implementation. Statistically significant negative correlations between extent of implementation of reorganization strategies and recovery were found in their study, replacements of staff and organisational restructuring should be done wisely. Radical changes in the structure of an organisation may lead to a negative organisational climate, lack of stability, mistrustfulness, and insecurity of positions. Nevertheless, it should be noted that the negative relationships found do not necessarily indicate that reorganization strategies should be avoided. Their study made a step towards dealing with the existing gap of knowledge and experience in the management of a failing public organisation. As these studies shows, further research in this area is required to fill the knowledge gaps.

\section{Revenue Generating Strategies}

Revenue generation refers to the way a company sells its products in order to make income. Arthur et al. (2005) noted that revenue generating strategie increase revenues and sales volumes are necessary. When there is liitle or no room in the operatings aim at generating increased sales volume. There are a number of revenue generating options that include price cuts, increased promotion, a bigger sales force, added customer services, and quickly achieved product improvements. Attempts to increase revenues and sales volumes are necessary. In some cases, especially in public corporations the government has major influences in influencing revenue generation through tax policies, regulations and even sometimes in terms of business policy.

Times of corporate distress present strategic management challenges. In such situations, a firm might be bankrupt or nearing bankruptcy, and often turnaround strategies will be sought. There are different techniques that can be applied to cause the turnaround. These include retrenchment, repositioning, replacement and renewal. Examples of reducing operations include eliminating low-margin or unprofitable products, selling buildings or equipment, laying off employees, and dropping low-margin customers. Organisations that employ turnaround strategy are usually forced into it and do so with the hope that it will be a temporary measure until things improve (Byars et al. 1996).

In the aspect of turnaround, government was found to be helpful in some cases of aiding in revenue generation such as in the case of Chrysler Corp (Chowdury, 2002). In the wake of 2008 economic crisis, cases like this were found to be quite common.

\section{Cost Reduction Strategies}

Cost reduction is the process used by companies to reduce their costs and increase their profits. Depending on a company's services or Product, the strategies can vary. Cost reductions must be supplemented with more drastic asset reduction measures. Assets targeted for divestiture are those determined to be underproductive. In contrast, more productive resources are protected from cuts or reconfigured as critical elements of the future core business plan of the company, i.e., the intended recovery response. Pearce and Robinson (1992) presented a model of turnaround based on evidence that business firm turnaround characteristically involved a multi-stage process in which retrenchment could serve as either a grand or operating strategy. Hambrick and Schecter (1983) pointed at asset cost surgery which will require significant reduction in research \& development, marketing receivables and inventories, selective product/marketing pruning, and increase in employee productivity.

Hofer (1980) conceptualized drastic cost reductions coupled with asset reductions were recommended for firms in more severe turnaround situations. Innovative turnaround strategies involve doing things differently whereas efficiency turnaround strategies entail doing the same things on a smaller or more efficient scale. Revenue generating through product reintroduction, increased advertising and selling efforts, and lower prices represent modifications in existing strategy can be classified as innovative turnaround strategies. In other words, innovative turnaround strategies involve product or market based activities while efficiency strategies focus on the production and management systems within the firm.

Jeyavelu (2007) attempted to build a case for including organisational identity concept into turnaround research and identified seven turnaround themes which included: top management change- this meant breaking from the past and it implies that managerial actions are not bound by history, there is a potential for creating a new identity; asset reconfiguration- this may include divesture, acquisition, merger, it implies a choice in organisational identity; organisational 
restructuring- this may include organisational redesign, business process reengineering, team based structure among others, the process of restructuring plays a critical role in achieving objectives of retaining or changing identity; strategic change- change in competitive and growth strategies, core competencies, domain changes, product or market changes, changes in strategies have the potential for changing identity, so it should be a choice; substantive changes in membership- these include retrenchment of workers, managers, voluntary retirement schemes, and shift from permanent workers to contractual workers, to constitute these, managers need to be aware of the impact of substantive changes in membership on survivors, retrenched employees and image, alternatives need to be actively considered in contexts where social security is absent, if necessary retrenchment processes should safe guard the individual's dignity in an honorable way and transformational change- this involves participative change, empowerment, change agent programs, mindset change, and culture change, transformational changes can reinterpret or transform the existing identity or create a new identity, organization wide changes that are likely to penetrate deep and remain for long in the organization, the cost of transformational changes should be balanced with the expected results.

\section{Organisational Performance}

In the twenty first century, organisational environments have continued to experience changes as a result of competition in the global market. Each change, be it technological, political, environmental or economical; these external changes exert pressure to organisations for them to remain competitive. Kenyan Corporation's existence have continued to be threatened and, therefore, the need to continuously improve their performance. The word "performance" is utilized extensively in all fields of management. Despite the frequency of the use of the word, its precise meaning is rarely explicitly defined by authors even when the main focus of the article or book is on performance. The correct interpretation of the word performance is important and must never be misread in the context of its use. Often performance is identified or equated with effectiveness and efficiency (Neely et al., 1995). Performance is a relative concept defined in terms of some referent employing a complex set of time-based measurements of generating future results (Corvellec, 1995). According to Richard et al. (2008) organizational performance encompasses three specific areas of firm outcomes including financial performance (profits, return on assets, and return on investment); market performance (sales, and market share); and shareholder return (total shareholder return and economic value added).

In Kenya, public corporations are registered under the State Corporations Act (Cap 446) Laws of Kenya, an Act of parliament that makes provision for the establishment of public corporations for control and regulation of public corporations and for connected purposes. The Kenya Government forms public corporations to meet both commercial and social goals. Some Public Corporations exist to correct market failures. This is the case, where, for instance, the service they give cannot be profitably provided by the private investors, for example tourism or infrastructure such as roads. Sometimes they exist to meet explicit social and political objectives: provide education, health or even redistribute income or develop marginal areas.

In management research, various indicators, both objective and subjective, have emerged to measure organizational performance. However, it has been difficult to operationalize the concept of performance (Lu \& Beamish, 2006) and there is a lack of consensus regarding the measures of performance in management field. Efforts to identify the variables associated with the organizational performance and what should be done with a view to attaining the results have been limited due precisely to the lack of comparison and reliability of alternative measures of business performance (Geringer \& Hebert, 1991). More exactly, there has not been a comprehensible explanation of the relevant variables that affect performance or development of a network of hypotheses for explaining and predicting organizational performance (Osland \& Cavusgil, 1996). Measurement of organizational performance is a controversial topic. This debate is associated with traditional financial/economic measures, for example, return on investment, profit, growth and returns sales (Chong, 2008).

In this context, Bucklin and Sengupta (1993) claim that economic or financial measures of performance, such as sales and profit, may not clearly reflect the quality of the Small and Medium Enterprises' (SMEs') performance, while Osland and Cavusgil (1996) state that profit, as an economic measure, is not directly comparable across different sectors and stages in the life-cycle of SMEs. Financial measures are objective, simple and easy to understand and compute, but in most cases, they suffer from being historical and are not readily available in the public domain (Chong, 2008). Sapienza et al. (1988), and Geringer and Hebert (1991) suggest that financial data are often not published, and when that type of data is made public, then it will be merely incorporated in calculations of financial performance. In fact, a financial or economic measure is unlikely to capture the relative performance of the firms.

The balanced scorecard (BSC), developed by Kaplan and Norton, has found wide acceptance in the private sector. Also, with its focus on customer satisfaction and organisational learning and growth in addition to internal process and financial aspects, it appears to provide a way forward in the public sector. The major players in the implementation of the BSC acknowledge the significance of the systemic dimensions necessary to underpin the framework. De Geus (1996) conclusions parallel the findings, from a different standpoint, of Kaplin and Norton. Kaplan and Norton, spent years researching the elements of successful organizations. They found that most organizations focus too heavily on "lag" indicators, such as financial statements and market share surveys, rather than on "lead" indicators to reveal the health of their organizations. The product of this research was the BSC, which is an outcomes oriented performance management system that seeks to link the short and long term activities of an organization with the vision, mission, and strategy of the organization through the establishment measurable, consensus-driven goals.

Kaplan and Norton (2001) explicitly recognized the systemic inter-relationship within and between four sectors, incorporating both lead and lag indicators, which impact on organisational performance. In their classic model, two of 
these have an inward oriented dimension, a learning sector and a processes sector, and two an external focus, a customer sector and the traditional financial sector.

Proropsaltis, Fulop, Meara, and Edwards (2002) conducted a study of UK hospitals to examine inadequacies in existing performance management systems. The results indicated that policy makers and managers need to develop a much more 'sophisticated diagnosis of the problems that caused the failure' in order to avoid simplistic solutions'. Furthermore, accurate identification of the reasons underlying an organisation's failure is a vital step in developing an appropriate recovery strategy. More work is, they claim, required to identify better markers for Strategies for organisational recovery. This is consistent with private sector research which suggests that rapid and decisive action is required for a successful turnaround.

Performance can be measured using objective or subjective self-reported measures. Although the use of objective measures would be preferred, obtaining accurate financial data is often a problem particularly in privately held firms. Dess and Robinson (1984) suggest that where objective measures of performance are unavailable or difficult to gather especially for private firms due to confidentiality, a researcher might consider using subjective perceptual data of these performance dimensions. In most public t corporations in Kenya the information required for this study is mainly considered confidential and therefore the respondents will be asked to compare their organisations with other public organisations on the indicators of organisational performance.

\section{Turnaround Strategy and Organisational Performance}

Many organisations decline due to falling sales, declining profits and more importantly declining demand. Demand in an industry declines for a variety of reasons (Harrigan \& Porter, 1983). Organizational performance and its improvement is a dominant theme in the field of strategic management. New substitutes emerge often with higher quality and or buyers shrink or simply disappear, changing customer needs, lifestyles and tastes also lead to declining demand, cost of inputs may increase and reduce demand for products. In such situations, top managers must find a strategy that will stop the organisation's decline and put it back on a successful path. The issue of organisational performance in the public sector has become increasingly important in recent years. The current Kenya Government's huge effort to monitor and measure the performance of public service providers has uncovered wide variations in the efficiency and effectiveness of different organisations.

According to March and Sutton (1997), organizations compete with one another, consciously seeking advantage. A major feature of that competition is competitive imitation. Poor performance rankings are interpreted by potential competitors as indications that a practice does not work or a market does not exist, thus inhibiting imitation and competition, thereby reducing the competitive pressure and improving relative performance. Good performance rankings, on the other hand, not only stimulate admiration; they also encourage imitation and competition that tend to erode a favorable position. Organizations seek to emulate the performance successes of others by emulating their organizational forms and practices. This practice is institutionalized through concepts of "best practice" and in the activities of managerial media and consultants. The result is the progressive elimination from net effect of organizational factors that are clearly relevant to performance advantage or disadvantage. This complication has often been used, by itself, to explain the relatively poor record of organizational research in explaining variations in performance. The basic idea is that any feature of organizational practice that might provide major competitive advantage is ordinarily adopted by all competitors. In this study the performance of the organisation was measured by the market share, asset growth, and service delivery depending on the industry/commercial setup of the organization.

After the publication of the sessional paper No.1 of 1986, SAPs have been integrated as policy tool for economic management; its adoption was aimed at restoring efficiency in all sectors of the economy (Rono, 2002). The implementation of SAPs has since evolved initially focusing on eliminating fiscal and external imbalances and reviving growth to involving liberalization of prices and marketing systems; financial sector policy reforms; international trade regulation reforms; government budget rationalization; divesture and privatization of public corporations and civil service reforms. The key ingredients of SAPs are based on an economic model of private ownership, competitive markets and outward-oriented development strategy. In his study of the impact of structral adjustment programmes on Kenyan society Rono (2002) observed that SAPs generally encompassed reduced relative expenditures on basic needs and socia services. Local products have been subjected to serious competition from imported ones and often from subsidized commodities. 
Moderating Variable

\section{Environmental Factors}

- Economic

- Resources

- Competitiveness

Independent Variable

\section{Turnaround Strategies}

- Revenue generation

- Cost reduction Figure 2.1: Conceptual Framework: Relationship between Turnaround Strategies
and Organisational Performance

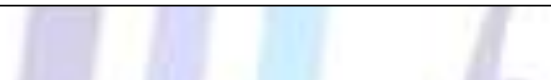

Dependent Variable

\section{Organisational Performance}

- Financial perspective

- Customer satisfaction

- Internal business processes

- Innovation and learning

this study, the dependent variable is the organisation performance while the independent variable is turnaround strategies as shown in the framework figure 1, As shown in Figure 2.1, these strategies are geared towards increasing revenue and reducing the organisation's costs. Performance was measured in four perspectives namely: Financial- summarizes measurable economic consequences of actions taken; Customer- contains measures that "identify the customer and market segments in which the business unit will compete and the measures of the business unit's performance in these targeted segments"; Internal Business Process- measures the internal processes in which the organization must excel; and Innovation and learning which measures the infrastructure that the organization must build to create long-term growth and improvement. The performance of the organisation was measured using balance score card model by Kaplan and Norton (2001).

Relationship between turnaround strategies and organisational performance is influenced by moderating factors such as resource allocation and environmental. The two variables, that is; revenue generating strategies and cost reduction strategies was tested using the Balance score card model developed by Kaplan and Norton, (2001) to determine the effect of turnaround strategies on organisational performance which is hypothesised by the researcher to be positive.

\section{RESEARCH METHODOLOGY}

\section{Research Design}

This study adapted a correlational design. The study used a cross-sectional sample survey where the relationship between turnaround strategies and organisation performance was tested. Data was collected over a period of two months.

\section{Target Population}

The target population comprised of Public Corporations within Kenya in various sectors such as agriculture, education, livestock, industrialization, transport, health, information and communication, housing, trade and industry among others, spread geographically across the country. There were 162 Public Corporations (Appendix II), (Office of the Prime Minister, 2012).

\section{Sample and Sample Design}

A sample of 32 public corporations was used for the study. To select 32 corporations purposive sampling was by identifying those Public corporations that implemented turnaround strategies to reverse their negative trends, among the 162 corporations, 139 public corporations implemented growth strategies and others divested. The selected corporations for this study were those that had adopted the turnaround strategies following the Economic Recovery Strategy for Wealth and Employment Creation (ERS) (Appendix III). 


\section{Data Collection}

To achieve the objectives of the study, both primary and secondary data was used in the study. Primary data was collected using a closed Likert-type scale questionnaire. The questionnaires were self-administered. The questionnaire was administered to one respondent from each selected corporation; the responded chosen was either Chief Executive of the corporation, a middle level manager or a senior manager who was familiar with the organisation's strategies and policy formulation. Primary data was complemented by secondary data extracted from available internal and external reports of the corporations, for a period dating not more than three years.

\section{Data Analysis}

The data collected from twenty one (21) corporations was edited, coded using Microsoft Excel software and keyed into SPSS computer software database, organized and checked for any errors that could have occurred during data collection. The data was then analyzed with the aid of the SPSS and Microsoft Excel 2010 computer software. Composite averages were analyzed using descriptive statistics. Pearson's product moment correlation and multiple regression methods of analysis have been used to analyze data. Pearson's product moment correlation was used to determine the relationship between turnaround strategies and organization's performance, and was found to be statically significant. The multiple regression model was developed as follows:

$Y=a+b 1 \times 1+b 2 \times 2+\varepsilon$

Where: $\mathrm{Y}=$ Organizational Performance, $\mathrm{a}=$ Constant, $\mathrm{b} 1-\mathrm{b} 2=$ Regression coefficients, $\mathrm{x} 1=$ Cost reduction strategies, $\mathrm{x} 2=$ Revenue generation strategies, $\varepsilon=$ Error term

\section{RESULTS}

\section{Effect of Turnaround Strategy on Organisational Performance}

\begin{tabular}{l|c|c|c|c|c}
\hline Model & $\mathrm{R}$ & R Square & $\begin{array}{c}\text { Adjusted R } \\
\text { Square }\end{array}$ & $\begin{array}{c}\text { Std. Error of the } \\
\text { Estimate }\end{array}$ & Durbin-Watson \\
\hline 1 & $.581(\mathrm{a})$ & .337 & .264 & .75005 & 1.715 \\
\hline
\end{tabular}

a Predictors: (Constant), Revenue Generating Strategies, Cost Reduction Strategies b Dependent Variable: Organisational Performance

The results of the regression analysis shown in Table 4.7 shows that the turnaround strategies accounted for $33.7 \%$ of the variance influencing overall organisational performance. This implies that $66.3 \%$ of the variance in overall organisational performance is explained by other factors not included in the model. The table below shows the full regression model.

\section{Full Regression Model}

\begin{tabular}{|c|c|c|c|c|c|}
\hline & \multicolumn{2}{|c|}{$\begin{array}{l}\text { Unstandardized } \\
\text { Coefficients }\end{array}$} & \multirow{2}{*}{$\begin{array}{c}\text { Standardized } \\
\text { Coefficients } \\
\text { Beta }\end{array}$} & \multirow[t]{2}{*}{$\mathrm{t}$} & \multirow[t]{2}{*}{ Sig. } \\
\hline & $\mathrm{B}$ & Std. Error & & & \\
\hline (Constant) & 1.127 & .802 & & 1.405 & .177 \\
\hline $\begin{array}{l}\text { Revenue Generating } \\
\text { Strategies, }\end{array}$ & .308 & .350 & .265 & .880 & .390 \\
\hline Cost Reduction Strategies & .369 & .316 & .351 & 1.167 & .259 \\
\hline
\end{tabular}

a Dependent Variable: Organisational Performance

$Y=1.127+0.308 x_{1}+0.369 x_{2}$

The full regression model shows that cost reduction strategies had a greater influence on performance $(\beta=0.351)$ compared to revenue generating strategies $(\beta=0.265)$. The regression equation indicates that an improvement in revenue generating strategies and cost reduction strategies positively affects organisational performance. Therefore the study's three hypotheses HA1: Cost reduction strategies have a positive effect on organisational performance, HA2: Revenue generating strategies have a positive effect on organisational performance and HA3: The combined turnaround strategies have a positive effect on organisational performance are supported by the study and therefore accepted. Therefore it can be concluded that there is a positive relationship between turnaround strategies on performance of public corporations in Kenya. 


\section{CONCLUSIONS}

From the findings of the study, turnaround strategies have effect on performance of public corporations in Kenya. When organisations implement turnaround strategies their performance improves; however, when the strategies are not implemented there is no significant improvement in their performance. Among the twenty one companies who responded $66 \%$ implemented turnaround strategies to an average moderate extent and their performance showed that they ranked above the middle $20 \%$. There is need to sensitize managers of organisation on these strategies, and tools of performance measurement. The study concludes therefore that there is a relationship between turnaround strategies and organisation performance. The study also revealed that cost reduction strategies has a greater effect compared to revenue generating strategies, however both strategies are complementary. From these study's findings the researcher also found that the turnaround strategies can be implemented when an organisation wants to turnaround from a decline, these accounted according to this study to $33.7 \%$. Other retrenchment strategies can be implemented to improve organisational performance.

\section{ACKNOWLEDGMENTS}

I wish to acknowledge God for His abundant guidance and grace. I also acknowledge the Egerton University, my supervisors, my family and my daughters Sandra, Shanna, Salma and my son Sean for their support.

\section{REFERENCES}

[1]. Abugre, C. (2000, June Retrieved May 4, 2008). The World Development Movement. http://www.wdm.org.uk/resources.

[2]. Arthur, A., Thompson , J., Strickland III, A., \& Gamble, J. (2005). Crafting and Executing Strategy. New York: McGraw-Hill//rwin.

[3]. Barney, J. (1997). Firm Resources and Sustained Competitive Advantage. Journal of Management, 1(17), 99 120.

[4]. Beeri, I. (2009). Turnaround strategies and Recovery in Local Authorities. National University of Ireland.

[5]. Bibeault, D. G. (1982). Corporate Turnaround: How managers turn losers into winners. New York: McGraw-Hill.

[6]. Boyne, G., Martin, S., \& Reid, S. (2004). Strategies for Organisational Recovery in Local Governemnt. Center for Local \& Reginal Government Research Cardiff University.

[7]. Boyne, G., Martin, S., \& Reid, S. (2004). Strategies for organizational recovery in Local Government. Cardiff University.

[8]. Bromiley, P. (1990). On the use of finance theory in strategic management. Advances in Strategic Management (JAI Press), Vol.6, 71-98.

[9]. Bryman, A., \& Bell, E. (2007). Business Research Methods. New York: Oxford.

[10].Bryman, A., \& Cramer, D. (2006). Quantitative Data Analysis with SPSS 14, 15 and 16: A guide for Social Scientists. London, New York: Routledge.

[11].Bucklin , L., \& Sengupta, S. (1993). Organizing Successful Co-marketing Alliances. Jornal of Marketing, 57(2), 32-46.

[12].Byars, L. L., Rue, L. W., \& Zahra, S. A. (1996). Strategy in a Changing Environment. Chigaco: Richard D. Irwin.

[13].Cater, J., \& Schwab, A. (2009). Turnaround Stratgies in Established Small family Firms. http://fbr.sagepub.com FFI-FAMILY FIRM INSTITUTE.

[14]. Central Bureau of Statistics (CBS). (2010). Economic Survey. Nairobi: Government Printer (Kenya).

[15].Chong, H. (2008). Measuring Performance of Small-and-Medium sized Enterprises: The grounded theory approach. Journal of Business and Public affairs, 2(1), 1-10.

[16]. Chowdury, S. (2002). Turnarounds: A Stage theory perspective. Canadian Journal of Administrative Science, 249-266.

[17]. Corvellec, H. (1995). Stories of Achievement: Narrative Features of Organisational Performance. Sweden: Lund University Press.

[18].De Geus, A. (1996). Strategy and Learning . Rotterdam: Rotterdam School of Management.

[19].Dess, G. G., \& Robinson, R. B. (1984). Measuring organizational performance in the absence of objective measures: The case of the privately-held firms and conglomerate business unit. Strategic Management Journal, 5(3), 265-273.

[20].Drucker, P. (1954). The Practice of Management. New York: Harper and Row. 
[21]. Finkin, E. F. (1985). Company Turnaround. The Journal of Business Strategy, 5(4), 14-24.

[22].Fisher, G., Lee, J., \& Johns, L. (2004). An Exploratory Study of Company Turnaround in Autralia and Singapore Following the Asia Crisis. Asia Pacific Journal of Mangement, 21, 149-170.

[23].Flynn, N., \& Talbot, C. (1996). Stratey and Strategists in UK Local Goverment. Journal of Management Development, 15.

[24].Gay, L. R. (1982). Educational Research Competencies for analysis and application. . Toronto: Merrill publishing company.

[25].Geringer, J., \& Hebert, L. (1991). Measuring Performance of International Joint Ventures. Journal of International Business Studies, 22(2), 249 - 263.

[26].Gibson, E., \& Billings, A. (2003). Best practices at Best Buy: a Turnaround strategy. Journal of Business Strategy, 6(24), 10-16.

[27].Goodman, S. (1982). How to manage a turnaround. New York: Free Press.

[28].Hambrick, D., \& Schecter, S. (1983). Turnaround Strategies for Mature Industrial - Product Business Units. Academy of Management Journal, 26(2), 231 - 248.

[29].Harrigan, K., \& Porter, M. (1983). End-game Strategies for Declining Industries. Harvard Business Review, 61(4):111-120.

[30]. Hofer, C. W. (1980). Turnaround Strategies. Journal of Business Strategy, 1, 19-31.

[31].Hofer, C. W., \& Schendel, D. (1978). Strategy Formulation: Analytical Concepts. USA, MN: West Publishing Company.

[32].Jeyavelu, S. (2007). Building a case for inclusion of Organisational identity in Turnaround Research. Research Paper, Kerala, India.

[33].Johnson, G., Scholes, K., \& Whittington, R. (1995). Exploring Corporate Strategy (7th ed.). London: Pearson Education.

[34].Jones, W. (1980). Agricultural Trade within Tropical Africa: Historical Background. New York: Praeger.

[35]. Kaplan, R., \& Norton, D. (2001). The Strategy Focused Organisation. Harvard Business Press.

[36]. Khandawala, P. (2001). Turnaround Excellence, insights from 120 cases.

[37].Kothari, C. R. (2004). Research Methodology: Methods and Techniques (2nd ed.). New Delh: New Age International Publishers.

[38].Landrum, N. E., \& Gardner, C. L. (2005). Using integral theory to effect strategic change. Journal of Organisational Change Management, 18(3), 247.

[39].Lee, C., Mathur, I., \& Gleanson, K. (1998). Corporate Response to Poor Performance: Evidence from UK and Canada. Journal of General Management, 24(1), 69-80.

[40].Lu, J., \& Beamish, P. (2006). Partnering Strategies and Performance of SMEs' International Joint Venture. Journal of Business Venturing, 21(4), 461 - 486.

[41].March, J. G., \& Sutton, R. L. (1997, November-December). Organizational Performance as a Dependent Variable. Organizational Science, 8(6), 698.

[42].Miringu, A. N., \& Muoria, E. T. (2011). An analysis of the Effect of Corporate Govrnance on performance of commercial State Corporations in Kenya. International Journal of Business and Public Management, Vol.1(1): 90 $-101$.

[43].Mugenda, M. O., \& Mugenda, G. A. (1999). Research Methods: Quantitative and Qualitative Approaches. Nairobi: Central Graphics Services.

[44].Neely, A., Gregory, M., \& Platts, K. (1995). Performance Measurement System Design. International Journal of Operational and Production Management, 15(4), 80-116.

[45]. Office of the Prime Minister. (2012). Public Sector Reforms and Performance contracting Kenya. Nairobi, Kenya: www.psrpc.go.ke.

[46].O'Neil, H. (1986). An analysis of the turnaround strategy in commercial banking. Journal of Managment Studies 23(2): 165-188.

[47]. Osland, G., \& Cavusgil, S. (1996). Performance Issues in U.S.-China Joint Ventures. California Management Review, 38(2), 106-130.

[48]. Osland, G., \& Cavusgil, S. (1996). Performance Issues in U.S.-China Joint Ventures. California Management Review, 38(2), 106 - 130. 
[49].Pant, H. (1991). An investigation of industry and firm structural characteristics in corporate turarounds. Journal of Management Studies, 6.

[50].Pearce, J., \& Robinson, R. B. (1992). Strategic Management Formulation, Implementation \& Control. New Delhi: Tata McGraw-Hill.

[51].Proropsaltis, G., Fulop, N., Meara, R., \& Edwards, N. (2002). Turning around failing hospitals. London: The NHS Confederation.

[52]. Rasheed, H. S. (2002). Turnaround Strategies for decling Enterprenneurial firms: The effects of performance and resources. Academic, North Carolina.

[53].Rasheed, H. S. (n.d.). Turnaround Strategies for decling Enterprenneurial firms: The effects of performance and resources. Academic, North Carolina.

[54]. Richard, P., Devinney, T., Yip, G., \& Johnson, G. (2008). Measuring Organisational Performance as a Dependent Variable. http://ssrn.com/abstract $=814285$.

[55].Robbins, D. K., \& Pearce 11, J. A. (1992). Turnaround: Retrenchment and recovery. Strategic Management Journal, 13, 287-30.

[56].Rono, J. K. (2002). The impact of Structral Adjustment Programmes on Kenyan Society. Journal od Social Development in Africa.

[57].Salamon, S. D., \& Robinson, S. L. (2008). Trust that binds: The impact of collective felt trust on organizational performance. Journal of Applied Psychology, 93, 593-601.

[58].Sanchez, R., \& Heene, A. (1997). Managing for an uncertain future: A systems review of strtategic organisational change. International Studies of Management \& Organisation, 27(2), 21.

[59].Sapienza, H., Smith, K., \& Gannon, M. (1988). Using Subjective Evaluations of Organizational Performance in Small Business Research. American Journal of Small Business, 2(3), 45-53.

[60].Schendel, D., Patton, G., \& Riggs, J. (1976). Corporate Turnaround Strategies: A Study of Profit Decline and Recovery. Journal of General Management, 3(3), 3 - 12.

[61].Sharma, A., \& Manimala, M. (2007, November). Sustainability of the Indian Railways Turnaround, India.

[62].Slatter, S. (1984). Corporate Recovery: Successful Turnaround Strategies and their implemention, Harmondworth, Middlesex: Penguin, London.

[63].Thompson, A. J., Stricland III, A. J., \& Gamble, J. W. (2005). Crafting and Executing Strategy (The Quest for Competitive Advantage) (14th ed.). New Delhi: McGrall-Hill. 


\section{Author' biography with Photo}

NAME:

Father's Name:

Marital Status:

Religion:

Date of Birth:

Contact Address:

Telephone:

E-mail:
Lucy Komen Birir

Albert Komen

Married

Christian

June $1^{\text {st }} 1972$

P.O. Box 591 - 20 100, Nakuru, Kenya

+254720738644

lucyalbertk@gmail.com

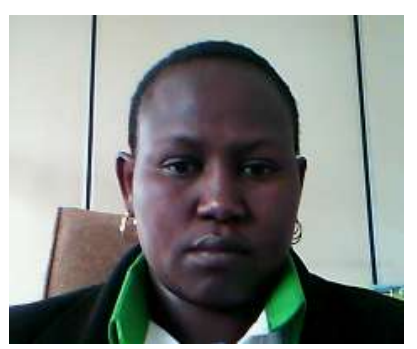

Areas of Specialisation: Marketing, Strategy Management, Organisational Management, Project Management and Report writing and Presentations

Lucy Komen received a diploma in business administration - information systems from Algonquin College, Ontario Canada in June 1995, a bachelor of business administration -marketing option from Kenya Methodist University in July 2008. She is currently finalising a master's in business administration at Egerton University, Kenya. In April 1996, she joined the Pyrethrum Board of Kenya's ICT department a systems analyst, in 2006 she moved to the marketing department as a customer relationship manager until 2009 when she was promoted to manage the business and market development department of the organisation. In 2013, she was added duties of managing the corporate communications of the organisation.

Lucy has participated in formulating the organisation's first ever strategic plan in 2001. She was involved in the Kenya Agriculture reform process which merged agriculture public corporations under one single authority; she played a major role in formulating regulations that will govern the Kenya pyrethrum industry. She has also been trained in ISO 9001:2008 top management training in 2012, market analysis and research in 2009, Microsoft certified system engineer cause and change management courses; she also participated in various industry workshops including a study on constrains to Kenya's exports trade with the USA. She has a great passion for the pyrethrum industry and wealth creation for the farmers in the Kenya agriculture industry. 